\title{
A theory of venturing: a critical realist explanation of why my father is not like Richard Branson
}

\author{
L. Galloway \\ I. Kapasi \\ L. Wimalasena
}

\section{Introduction}

Richard Branson started his first business, a student magazine, in the 1960's and today is worth over \$4 Billion (Forbes, 2019). Around the same time, the father of one of the authors of this paper started a business as a painter and decorator, but today he remains a sole-trader and he is not worth $\$ 4$ Billion. These dissimilar cases exemplify the diversity of business venturing. The Oxford English Dictionary defines venturing as "undertaking of risk; commercial speculation". Applied to individuals, this is an independent activity, distinct from waged employment, and can range from low value self-employment, such as low-skilled piece-work, through to innovation-based, growth-oriented prospects, such as a high-tech start-up. Currently there is little theoretical engagement with the diversity of business we observe though (Ogbor, 2000; Steyaert and Katz, 2004; Welter, Baker, Audretsch and Gartner, 2017). Instead, most research has focused on inspecting just a small subset of businesses, those we describe as 'entrepreneurial', generally based on post hoc exhibition and/or anticipated potential of substantial financial contribution. But empirically, the shape and scale of venturing is entirely variable, heterogeneous and complex.

In this paper, we address the misalignment between research and empirical observation by exploring business venturing as a human activity conducted in social and personal contexts (Zahra, Wright and Abdelgawad, 2014). With reference to current developments in the literature, we explore the central venturing components of opportunity and value, and while 
often conceptually positioned as discrete, we assert these are in fact interrelated. Moreover, while economics-based research has prioritised economic measurements, we argue that opportunity and value are subjectively and inconsistently understood by individuals in contexts and may include, or even prioritise, social and personal factors over financial ones. Consequently, we explore the ontological and espitemological underpinnings of the central questions, Opportunity for what? and What value?

We draw specifically from the critical realist morphogenetic approach developed by Margaret Archer (1995, 1998, 2000, 2003, 2007). According to Archer, individuals interact with social structures and this interaction between agency and structure produces (expected and unexpected) consequences that lead to reproduction or transformation of the social context. In turn, social contexts present both constraints and enablers to individuals as they pursue life goals. The means by which individuals negotiate agency and structure is through the dialectical process of personal reflexivity. Since context and individual factors evolve over a lifetime, the activities of, and outcomes for, individuals as they reflexively engage in society are myriad (Elder-Vass, 2010). We propose that this is as applicable to business venturing as any other human activity that is socially situated, and affords an inclusive non-deterministic view of venturing.

The main contributions of this paper are the reconceptualisations of opportunity and value and the use of critical realism and reflexivity to inform understanding of venturing. This provides clearer understanding of how and why business venturing occurs and better representation of the highly variable business landscape we empirically observe. By exposing the driving forces of venturing we can even explain why the author's father is not like Richard Branson; their different personalities, habitual behaviours (backgrounds), skills and ongoing experiences are all critical shapers of each man's reflexive choices, ultimately resulting in dissimilar business and life trajectories and outcomes. 
The paper starts by problematizing gaps in knowledge about business venturing vis- $a$-vis it being a range of activities with a wide range of originating circumstances and ultimate outcomes. The following sections explore key dimensions of business venturing: opportunity, value and action, considering current conceptualisations of these. By adding the key dimension, reflexivity, a new theory of venturing is presented as Figure 1, and the underpinning critical realist morphogenetic rationale is outlined. Following this, a temporally informed model of the venturing process over a lifetime is presented in Figure 2. Some evidence that supports the theory is proposed in the sections that follow, and implications for theory development and for policy on venturing are articulated. The paper concludes with a summary of the contribution and utility of the critical realism-based theory.

\section{Research: entrepreneurship or venturing?}

Studies of 'entrepreneurship' broadly fall into two categories. First, there are studies that refer to all business venturing - business creation and self-employment - as entrepreneurship and often they comprise macro, scoping accounts of the rates of businesses or start-ups in an economy (e.g. Kelley, Singer and Herrington, 2016). In these studies, activities that are clearly not the same are conflated; a self-employed taxi-driver is not the same as a high tech start-up team, and as per our opening example, Richard Branson and the author's father have not enjoyed similar business experiences. Elsewhere, the second type of 'entrepreneurship' study treats entrepreneurship as a separate and special category of venturing that involves financial growth propensity and usually innovation (e.g. Bygrave and Hofer, 1992). Because of superior anticipated potentials and subsequent financial achievements, it is the strategies and operations of this type of venturing that have been explored most often (Bygrave, 1994; Steyaert and Katz, 2004; Wiklund and Shepherd, 2003). The cumulative picture, therefore, is that venturing is counted across a spectrum of diverse businesses, but only the specific financially lucrative 
types have been inspected to any great degree. And this inspected category is small - in most developed nations micro-business and self-employment account for more than 90 percent of all venturing, suggesting entrepreneurship, when defined as financial growth-orientation, is represented by only a fraction of the business population (e.g. see UK statistics in Young, 2013). The result for policy, practice, and indeed knowledge, is that we know there is lots of venturing but we know very little about the vast majority of it (Manolova, Brush, Edelman and Shaver, 2012; Anderson, 2015; Welter et al., 2017). As a consequence, in this paper we purposefully avoid the term 'entrepreneurship' since its conceptualisation is inconsistent and, when used to mean high financially performing venturing, lacks clear paramenters - there is no precise financial growth pace that classifies a firm as entrepreneurial.

Common to all business venturing, there are key dimensions: there must be a perceived opportunity to venture; there must be some perceived value attributed to it; and an individual has to act to take that opportunity to realise that value. In this paper we explore these three dimensions and add a fourth, reflexivity, to explain that venturing is comprised of the actions to respond to an opportunity to realise value, but that both the opportunity and the value are reflexively understood. The four dimension approach thus requires opportunity, value, reflexivity and action. This is illustrated in Figure 1.

Figure 1 here

The following sections explore the four dimensions and show that by taking a critical realist perspective we can examine how reflexivity is core to venturing.

\section{Exploring business venturing}


Economics-based research has largely explored all venturing from a functionalist perspective, where that function is understood to be development of financial wealth ${ }^{1}$ (Welter et al., 2017). The key components of opportunity and value therefore have been widely interpreted as opportunity to realise financial value; as Tedmanson, Verduyn, Essers and Gartner (2012, p. 532) put it, economics-based theories present the venturer as "homo economicus, driven entirely by financial motives". In turn, throughout the extant literature, any other (nonfinancial) drivers and outputs are treated as subordinate, or not considered at all.

But in fact there are lots of reasons why people engage in venturing and an enormous range of ventures. Each is the outcome of an opportunity perceived and subsequently taken to realise some value. But value is not an exclusively financial property; it is perceived subjectively by, and inconsistently among, individuals. Consequently, we explore the key questions prompted by Figure 1: Opportunity for what? and What value?.

\section{Opportunity for what?}

Since the seminal work of Shane and Venkataraman (2000) there has been much development in research regarding the conceptualisation of opportunity (Alvarez and Barney, 2010; Gaglio and Katz, 2001; Ramoglou and Tsang, 2016). Indeed, according to Ramoglou (2011), opportunity has become established as the 'conceptual standard' for research investigating venturing (p.439) (see also Short, Ketchen, Shook and Ireland, 2010). However, whilst the opportunity concept is strongly defended (e.g. Wood and McKinley, 2018), there is some interrogation of the applicability and validity of it (e.g. Davidsson, 2017). Kitching and Rouse (2017), for example, question whether opportunity has a place in understanding venturing action at all, and they draw particular attention to the issues surrounding its ontological and

\footnotetext{
${ }^{1}$ The exception to this is in studies of social enterprise, where social goals directly replace financial ones. Most often these are presented in the same procedural way, despite measurement being vague.
} 
epistemological use, particularly in terms of the debate on whether it is a subjective or objective referent. Either way, opportunity has traditionally been interpreted as an opportunity to increase financial yield (whether personal or on an economy) (e.g. Shane, 2003; Short et al., 2010; Aparicio, Urbano and Audretsch, 2016). Recently though, this has been criticised as tautological, or at least, its "referents are highly elastic" (Kitching and Rouse, 2017, p.2; Ramoglou and Tsang, 2016). Ramoglou and Tsang (2016) argue that the assumption that business is driven by ambition for financial outcomes is based on post hoc attribution of financial value to define 'successful' business. Consequently, to avoid eliminating from analyses those that have not (yet) achieved financial value-adding, they refer to financial propensities and profit potential in Ramoglou and Tsang (2016) and Ramgolou and Tsang (2017) respectively. We take this one step further and question the primacy of financial criteria in the perception of an opportunity at all. While acknowledging the need for business to provide financial return sufficient to enable some personal income, there is no a-priori reason why a perceived opportunity should always or exclusively relate to opportunity to realise financial value.

We argue that rather than tautological, the assertion that venturing requires financial ambition is circular reasoning - research studies have never omitted financial value-adding as an outcome $^{2}$ and have assumed it as an antecedent to all business, most often exclusively. We assert instead that opportunity is the perception of some realisable value potential, but that this may be any outcome sought by an individual. In this sense, (perceived) opportunity is inextricably linked to (perceived) value, and this is explored next.

What value?

\footnotetext{
${ }^{2}$ Again, social value replaces this financial focus in the social enterprise context.
} 
As for opportunity, Hessels, Gelderen and Thurik (2008) and Donaldson and Walsh (2015) criticise the understanding of value only in financial terms, asserting instead that, conceptually, value can be multiple for individuals and society (Donaldson and Walsh stress the value of dignity in their paper). In a similar vein, Gritzas and Kavoulakos (2016) note that all capitalist economies are heterogeneous spaces where multiple processes and mechanisms of exchange occur, and consequently, there may be many modes of organising or categorising 'value'. Consistent with this, Lee (2006) proposes that value is diverse and heterogeneously perceived, as do Gibson-Graham (2006, 2008, 2010). In their critical appraisal of established wisdom on the structures and operations of neoliberal society, Gibson-Graham (2010) demonstrate that there are multiple economies at play. They note that much of this is not based on financial return or commodification at all, asserting instead that non-monetised practices operate concurrently with market ones within each of the structural pillars of capitalism, including for example, unpaid work, gift giving, and in-kind exchanging. Recent figures from the UK show that unpaid work accounts for more than half of Gross Domestic Product (GDP) (Office for National Statistics, 2016), providing further empirical evidence that value is not always financially commodified. There may be cost-benefits of course - housework for example may save the costs to a family of employing a cleaner, but in and of itself, there is no financial value assigned to this work; the value is a clean home and the itinerant advantages of this, such as health, lifestyle and aesthetic benefits. Thus, value is not always or necessarily associated with financial factors, and this may also apply in the domain of business venturing.

Traditional approaches to business propose that to be viable, venturing must include profit; it must involve selling something at more than it cost to produce. This basic economic principle is neither conceptually stable nor consistent though. Take for example, the author's father. In an employing firm context the costs of a painting and decorating service are materials and labour. In developed economies, labour is subject to a minimum hourly rate set by governments 
as a threshold beneath which the costs of living may not be serviced. In a self-employed context (or as the owner of a business), a painter and decorator might accept an hourly rate of pay lower than minimum wage. Indeed, in a competitive environment, business will be won by those able to accept the lowest price. In an employing firm, according to traditional approaches to business strategy (e.g. Porter, 1996), this would constitute trading at a loss and the business would fail. Alternatively, in the business venturer context, this is tolerated and the business considered sustainable. Thus, while some financial value-adding must be realised, the extent of it is highly variable, and includes trading at the very margins of business feasibility. This suggests that some individuals believe that some other, non-financial value may also be realised by venturing.

Shepherd, McMullen and Jennings (2007) and Wood, McKelvie and Haynie (2014) use the term value-belief to clarify that value sought may not be value actually achieved; an individual believes (fallibly) that some outcome will be valuable, but that cannot be (subjectively) confirmed until it is realised. Personal satisfaction, work/life balance, personal identity, skills development are all examples of potential non-financial venturing-related value-beliefs, and there is no a-priori reason why these would not be considered alongside, or even prioritised over, financial returns for some individuals. This makes possible the idea that venturing can be prompted by the perception of an opportunity to realise some financial and/or non-financial value-belief, and this may include myriad interpretations, each idiosyncratic to an individual in context. Most studies of business do not allow for this because of the primacy and exclusivity attributed to financial opportunity and value in economic approaches.

The next section explores how critical realism may be a useful means of exploring diverse forms of value and opportunity. 


\section{Critical realist morphogenetic theory}

Critical realism affords explanation of social phenomena by postulating three central pillars. First, the existence of society depends largely upon human action. Second, society is constantly being recreated and transformed by such human action. Finally, the nature and actions of individuals are also shaped by the particular social context in which they live. To elucidate, Bhaskar (1979) proposes a stratified ontology to explain our social world, whereby there are different 'levels' of reality; the real, the actual and the empirical. The real refers to structures, mechanisms, powers and relations that exist and that cause events to occur. The actual refers to events and actions that happen even if we do not experience them. The empirical refers to that which we experience and includes our perceptions (Danermark, Ekstrom, Jakobsen and Karlsson, 2002). Critical realist theory posits that reflexivity is the means by which people engage with reality; it is how individuals make meaning at the level of the actual and how empirical outcomes are caused (Maccarini and Prandini, 2010).

In critical realist theory, both structure and agents have causal powers and these are engaged through reflexivity (Archer, 2003; Lopez, 2009). As such, while individual behaviour is causally affected by the emergent powers of social factors, human beings also possess causal powers of their own, that is, their ability to exercise agency through reflexivity (Archer, 2007; Elder-Vass, 2008; Suddaby, Viale and Gendron, 2016). These interactions of agency and structure are called 'morphogenetic cycles'. For an individual, this process of mediating social influences through reflexivity is lifelong, and over the cumulative and overlapping lifetimes of individuals in society, endless morphogenetic cycles create 'social elaboration' (Archer, 1995). Society is thus a cumulative outcome of human actions, and is being constantly recreated and transformed. In turn, this influences individuals' circumstances, including their roles and identities as they are relationally informed by the social culture within which they are embedded. 
We propose the critical realist morphogenetic approach to understanding social phenomena has utility for understanding business venturing in two ways. First, since individuals' reflective perspectives and approaches to life are idiosyncratic, socially influenced and context bound, diverse and myriad antecedents to venturing are possible. Second, diverse venturing antecedents will result in diverse venturing outcomes. These are the underpinning principles of the four-dimension theory modelled in Figure 1. Via this theory, the diversity of businesses we observe is illuminated, as are the means by which diversity is generated. This is explored further in the next section.

\section{Theorising venturing}

In business and entrepreneurship studies, there has been a tendency to overlook the entangled nature of the individual and society as co-related and co-dependent. Instead, business research has tended to explore the effects of structure and agency on venturing by considering them in isolation - 'that either social (and venturing) behaviour is determined by structural forces or it is determined by the free choice of human individuals' (Elder-Vass, 2008, p.3 emphasis in original). This is conflationary theorising, as the effects of either structure or agency are prioritised. In business studies, where there has been prioritisation of agency over structure (upwards conflation), intention has been attributed primacy (Bird and Jelinek, 1988; Dimov, 2007; Bae, Qian, Miao and Fiet, 2014). This has been applied on the basis that venturing requires action (McMullen and Shepherd, 2006; Dimov, 2007), action occurs as a consequence of agency, and this implies intent (Ajzen, 1991). However, the ventures observed in the world are not all clearly explained by agential intention (Welter et al., 2017). It does not explain, for example, venturing where the employment norm is self-employment/business, such as farming or trades. Neither does it explain why rates of venturing fluctuate, such as increases in selfemployment in adverse economic circumstances in response to job market contraction 
(Bögenhold and Staber, 1991). Thus, it is not credible to explain venturing actions simply from the intentions of an individual without reference to their context, and indeed, in the wider literature on motivations, agency-based approaches to intention have been found to be inadequate in explaining social phenomena (Armitage and Conner, 2001; Sniehotta, Presseau and Araújo-Soares, 2014).

In contrast, prioritisation of structure over agency to explain venturing (Karp, 2006; Korsgaard and Anderson, 2011; Anderson, 2015), results in downwards conflation since it underplays the role of the individual to negotiate their surroundings and choose life paths. People clearly do make choices in their lives and in the case of venturing, sometimes people do 'choose' to venture. In turn, their choice and the myriad potential personal, business and social outcomes can and do affect the environment - consider the globally transformative effect of Bill Gates or Henry Ford's decision to create their firms, or even the effect on a high street of a new opportunity actualised.

As an alternative approach, critical realism affords analytical dualism whereby the analytically distinct agency and structure may both be considered, and it is the interplay between them that results in outcomes. Thus, rather than reference venturing within individual or social circumstances, it is reflexive engagement between the individual and the social that informs (perceived) opportunity to realise (perceived) value; reflexive engagement between individuals and their circumstances is necessary for opportunity and value to be perceived meaningfully and subjectively by agents, and from this action is prompted. For venturing to occur, therefore, the four mechanisms of reflexivity, value, opportunity and action are mandated, as per Figure 1. The business-oriented actions to realise perceived opportunity to achieve perceived value, reflexively understood, are business venturing - from informal self-employment to business empires. 
This is not the first attempt to apply critical realist approaches to venturing of course. Boxer, Perren and Berry (2016) for example, refer to the morphogenetic qualities of reflexive practice in small to medium-sized enterprises (SMEs). Clark and Blundel (2007), Fuller (2013) and Lichtenstein, Carter, Dooley and Gartner (2007) refer similarly to reflexive engagement of structure and agency in the business domain, maintaining that the decision to venture is linked with individuals' perceptions of associated social identities and positions. Further empirical support for this position is found in Elfving (2008), Kurczewka, Kyro and Abbas (2014) and Meliou and Edwards (2018) in that motivations for business creation are demonstrated as context and circumstance bound and based on an individual's reflexive perception. Of specific relevance to this paper, opportunity has been scrutinised through a critical realist lens (also Clark and Blundel, 2007; Martin and Wilson, 2014; Ramoglou and Tsang, 2016). In particular, Ramoglou and Tsang (2016) argue that opportunity is objective, i.e., the mechanisms for venturing opportunities always exist at the level of the real. While not contesting this, we argue that opportunities become actual when individuals reflexively engage with them, therefore perception of opportunity is based on perception of value (value-belief) and these are individualistic and circumstances-bound, and therefore subjective. This means for venturing that different causal factors (individual and circumstantial) at the level of the real will result in myriad perceived opportunities to realise myriad value-beliefs at the level of the actual and ultimately myriad empirical (business) outcomes will ensue.

To illustrate, we use the analogy of an egg. According to critical realism an egg is either real or actual (depending on one's position on whether the chicken or the egg came first). Assume in this instance that the egg is real - i.e. that it may cause food. Before that egg becomes consumable, an agent has to identify what outcome is sought - is this a snack, a breakfast, an ingredient in a recipe for a meal for several people? This is based on any number and manner of other variables, that include both environmental (structural) ones (such as the availability of 
other ingredients, equipment, sources of power), and personal (agential) ones (such as whether or not the agent has the skills to cook the egg, ethical concerns, how they are feeling that day, and what kind of egg-based food they have a notion for). Each of these environmental and personal factors is, in turn, contingent on myriad influences. As a consequence of causal dynamics in the specific circumstances, the egg, at the level of the empirical, will become scrambled, poached, boiled, or form part of a cake or an omelette perhaps. The egg has a range of potentials - indeed, it may even stay an egg if the agent changes his mind, perhaps on discovering porridge.

Via this same process, based on an individual's reflexive engagement with personal and external factors, a perceived opportunity becomes venturing of some sort, or indeed, no venturing at all if circumstances or perceptions of value change. Like the egg, at the level of the real, opportunity has the potential to become any number of empirical outcomes. Thereafter, as a consequence of personal, environmental or habitual behaviour factors in an individual's life to date, an opportunity to realise value by venturing is perceived. But this is contingent on two main components. First, myriad contextual and personal dynamics are involved. Availability of other work options, access to capital, skills levels, etc. - each of which is also shaped by personality, experiences and social and cultural context - all will influence business propensity and outcomes. Second, what is the value sought from the opportunity opportunity for what? - to make income, stay active or build an empire? It is an individual's reflexive engagement with opportunity idiosyncratically perceived, their personal and environmental circumstances, and the value sought that shapes causality, which is multidimensional and dynamic. As a consequence of actions in an individual's specific circumstances, at the level of the empirical what emerges using the theory modelled in Figure 1 may be a high-growth firm, a lifestyle firm, self-employment, or even no venturing if an interesting employment opportunity emerges perhaps. Through this process, at a macro level, 
venturing outcomes will therefore range from Branson-esque business empires, through to selfemployed decorators. In turn, the cyclic, morphogenetic properties of reflexivity mean that these venturing outcomes become part of the social world. As such, venturing plays a part in social elaboration; over time, the outcomes of venturing affect and alter the environment. This explains how and why the business landscape is constantly developing.

Further, since reflexive interaction between individual and context is a lifelong process (Archer, 1995, 2003) venturing is consequent to individuals' reflexive engagement with the social influences on them throughout their life-course. The theory of venturing developed in this paper therefore allows that there will be continuous reflexive engagement of individuals with opportunity and value idiosyncratically defined and not exclusively (or necessarily) financial, throughout their lives. As such, venturing itself can also be seen to be part of the morphogenetic process; venturing will afford capacity building and other experiences for individuals that will inform ongoing careers, including other forms of venturing at life stages as the value required of opportunities evolves. This is represented in Figure 2, which illustrates the venturing process over a life-course.

Figure 2 here

Figure 2 illustrates that as value and opportunity perceptions alter over a life-course, so too can venturing and that this is a morphogenetic, reflexive process. Some evidence that supports the validity of this theory is presented in the next section.

\section{Some evidence of venturing reflexively motivated and achieved}

In recognition of the diversity of business activity that we observe throughout the world, Figure 1 illustrates new theory that considers factors that may affect the stimuli for action in the 
business domain. Further, in terms of its morphogenetic properties, the four dimension theory allows that perceived value and opportunity change over a lifetime, as illustrated in Figure 2.

There is some supporting empirical evidence of the applicability of this throughout the literature. For example, in terms of the perceived value of venturing, the attractions of autonomy and status have long been identified (Walker and Brown, 2004; Van Gelderen and Jansen, 2006). Similarly, in the female business literature in particular, there is evidence that lifestyle flexibility to manage competing domestic and economic priorities is perceived (Orhan and Scott, 2001; Morris, Nola, Craig and Coombes, 2006). Beyond the aspirations of founders, the UK's Office for National Statistics (2014), identifies industry sectors dominated by venturing as the norm, such as farming, trades and hospitality, and Marks and Huzzard (2010) report an increase in private venturing in the IT industry as the sector shifts from an employment norm to one based on self-employed contract work. In these cases, the pursuit of profit value proposition is less likely than pursuit of employment as the value for individuals.

While not an exhaustive list, these belie the traditional wisdom that financial value-adding is the only or even the main value-belief for some business venturing. Opportunity is perceived in each case - sometimes a classic market opportunity, other times, the opportunity just to work in a hostile labour market for example. Each is a unique reflexive response to the unique context and personal circumstances of the agent. The value realised may include financial measures, such as income for the venturer and profit, but in fact the venturing may not be economically driven at all. Mochrie, Galloway and Donnelly (2006) and Jones, Simmons, Packham, BeynonDavies and Pickernell (2012) found remaining small and avoiding financial growth to be a deliberate strategy amongst some of their small firms samples. Similarly, in their study of older venturers, Stirzaker, Galloway and Potter (2019) found that most of their sample were attracted to venturing as a means of reducing their economic activity compared with their previous careers; the opportunity and value-beliefs were largely intrinsic, relating to purpose, esteem, 
enjoyment or desire to stay active. In these examples, the extent to which venturing realises value is not diminished, it is just not monetised in the same way or to the extent that economic theories would have us expect, resonating with findings in Gibson-Graham (2010) about the value of activities being broader than that defined only by financial return.

In other words, value varies and means different things to different people. We argue further that for venturing, different forms of value-belief may include financial consideration, but that this is not absolute. However, the extent to which financial considerations are included in the value proposition is a means by which we might identify different types of venturing, and it is to this that we now turn.

\section{Different types of venturing}

Contemporary theories propose that 'entrepreneurship' is a type of venturing explicitly involving development of financial value (Shane and Venkataraman, 2000; Alvarez and Barney, 2010; Martin and Wilson, 2014; Ramoglou and Tsang, 2016). The precise point at which business becomes definable as entrepreneurial may therefore be represented as the point where an increase in the financial value of the business is pursued. This being the case, the use of business start-up rates as a proxy for entrepreneurship in studies of business venturing is not entirely inappropriate. Where there was once no business, new business has been created. However, we argue that start-up rates are only a proxy for the potential of entrepreneurship (when defined as financial growth-oriented venturing). Despite this potential once a venture is created and is enabling whatever the reflexively understood value-belief is (income and/or other), further financial value-adding is not exhibited by the majority of venturers. Instead, the majority maintain the current idiosyncratic value and exhibit only limited development. Growth-oriented venturing may thus require that opportunity-belief is understood as including 
financial development opportunity and value-belief as including financial growth. These may be alongside other opportunities/value, such as identity as a successful business man/woman, or may even be antecedents to some other prioritised value, such as an identity as a technology disruptor. Subsequently, action must be taken to realise this financially-oriented opportunity and value, and might include human and financial capital investment, etc. For less financially ambitious business activity there may be constraints, such as skills or resource deficits, and/or alternative prioritised opportunities and value-beliefs, such as to work flexibly, to have work at all, or to work in a specific industry where venturing is the employment norm.

The distinction between financially growth-seeking and not growth-seeking venturing is not binary of course, and instead venturing is a spectrum based on myriad structural and agential influences and constraints. Ventures are also dynamic though and as such may change over time. A business started by a parent of young children, for example, to afford lifestyle flexibility by reducing working hours, may yet become a higher financially performing business when children grow up. The suggestion in this example is that capacity building and experience will yield higher value ventures over a life-course. This may well be true, but equally it might inform other work options, including not to venture again. Individuals may venture for any number of reasons, including even to reduce their economic activity, such as during a period of ill health or in older age, when rather than maximising profit and developing financial valueadding, individuals may accept and experience a drop in income.

The cumulative effect is a landscape of complexity and diversity in terms of business outcomes. The four dimension theory affords explanation of venturing that better represents that empirically observed. It allows that Richard Branson may venture to increase financial circumstances and that the author's father may venture to service local family life, and that their motives are inextricably linked to their backgrounds, environments and experiences. 


\section{Implications for research}

Conflationary theorising has led to a mismatch between theory about venturing and the outcomes of venturing empirically observed. Whether underpinned by agency-based theories or structure based ones, any one-dimensional approach will render understanding of the diversity and complexity of the venturing landscape as incomplete. Alternatively, using the critical realist morphogenetic approach, our understanding of the venturing process is informed. The theory modelled in Figure 1 avoids conflationary theorising and instead presents venturing as idiosyncratic and reflexively achieved. Value is understood as unique to individuals and informed by greater socio-cultural context. Perceived opportunity to realise some value-belief is based on subjective but socially-informed perceptions of value and the theory thus allows that the shape and scale of venturing is entirely variable between the poles of contract work or self-employment and growth-oriented business development. Beyond this, since value may change for individuals over time, so too may opportunity perception and actions taken throughout a life-course. The morphogenetic properties of the theory of venturing proposed in Figure 2 allow unpicking such morphogenetic cycles for the purpose of analysis and understanding, whereby venturing may be a recursive process consisting of endless cycles owing to divergent and evolving agential and structural conditions.

Empirical work based on these propositions is likely to be revealing both in terms of testing the theory and in terms of exploring new empirical evidence that has been long overlooked in the business literature. In particular, we anticipate clarity as a consequence of the resolution of ontological conflation of structure and agency, and a robust position in terms of the mechanisms of venturing from which to undertake research regardless of the subsequent epistemological stance. Additionally, since opportunity is fundamentally intersected with value and financial criteria are not mandated, we may explore business outcomes from wider perspectives. Within the broader social science context, qualitative-led enquiry has identified 
the subtleties of structural impacts on agents and their reflexivity. Another area for future research might be to consider how critical realist-based enquiry might also capture these nuances for venturing across different social strata, such as class and gender as well as in different socio-economic contexts beyond developed neoliberal economies. Finally, since time is a key mechanism in venturing over a life-course, longitudinal studies of people who have ventured and do or do not continue to venture, would be revealing.

\section{Implications for policy and practice}

The study of entrepreneurship, as a specific financially-oriented subset of venturing is often directed by aspirations to pick 'winners' and support high growth firms (e.g. Parker, Storey and Witteloostuijn, 2010). However, with the scale of venturing encompassing a diverse range of businesses functioning disparately, identification of truly lucrative propositions can become lost in the 'noise' of diversity. We make the case that by clearly distinguishing the necessary mechanisms for venturing to occur - reflexivity, opportunity, value and action - we can begin to unpick the co-mechanisms of those firms that have the potential and capacity at the empirical level to make high economic contribution and transformation. At this end of the venturing spectrum there will be some high potential firms, what Parker et al. (2010) refer to as 'gazelles', along with other financially lucrative prospects. Conceptual clarity will assist the informing and directing of policy to identify and appropriately support these ventures.

More broadly, we argue all venturing may be socially and/or economically contributory, but since the contribution varies, so too should appropriate support and policy responses. In the case of innovation-based and/or growth-oriented ventures, jobs may be created, value added regionally or nationally, and a strong finance sector and resource for innovation might be implied as support requirements. In other examples, such as earning while parenting, working 
in a sector where self-employment and business are the employment norms, or venturing as a consequence of lack of employment alternatives, contribution is also made. There are the contributions and value of, for example, parenting, skills development and job creation for founders. In addition, there are cost benefits, including mitigation of the costs of welfare/unemployment and others associated with underemployment, such as health and wellbeing costs. All types of venturing have nuanced implications for policy and support and since each has the potential to be socially and/or economically contributory these may be as compelling as the need to encourage and support high growth venturing. In short, venturing, whatever its prompts, can be positive and contributory and if understood well, might be supported most effectively.

\section{Conclusion}

The value of this work is in its re-examination of why and how venturing occurs. We argue that current means of understanding business venturing are limited as they are underpinned by notions of opportunity and value that have been highlighted as conflationary, hegemonic and even circular reasoning. On the basis that value has traditionally been assumed to be financial, inspection has prioritised growth-oriented venturing, where an unspecified but large economic potential is anticipated. There has been little inspection of other types of venturing. We argue here that if we are more inclusive in terms of what we mean by opportunity and value, in particular opportunity for what? and what value?, and allow that these are reflexively understood by people in contexts, conceptualisations of venturing are more robust.

As with all research, this conceptual reconsideration of business venturing has limitations. First, the empirical evidence for opportunities sought and value ascribed beyond the financial is limited, and what evidence there is has been inferred in this paper rather than directly 
observed by the researches from which they are drawn. Nevertheless, the paper makes four specific contributions to the development of theory and understanding. First, venturing is presented as a reflexivity-informed phenomenon, driven by unique agential and contextual interactivity. By taking a morphogenetic approach to understanding empirical action, analytical dualism allows researchers to explore both agent and context (and their interaction) rather than rely on conflationary theorising that prioritises one over the other. Second, there is contribution to the development of understanding opportunity in venturing. Opportunity to venture is perceived and taken in the context of, and as a response to, the attribution of some reflexively understood value-belief; an individual anticipates that some subjective value will be realised by an opportunity and as that value-belief varies among individuals, so too does the perception of the opportunity. Third, the models presented in Figures 1 and 2 illustrate that venturing is a temporally-informed process. The attribution of value-beliefs to opportunities to venture may change for individuals over time as the value sought by them evolves in concert with an evolving environment and progression through a life-course. For those who venture, venturing itself becomes part of this reflexive process that will impact ongoing venturing (or no venturing) actions and outcomes. Finally, the reconceptualization of venturing predicated on reflexive engagement with myriad social, environmental and personal circumstances leads to myriad venturing outcomes, including (but least likely) high growth firms, and this provides a better representation of the diversity of the business landscape empirically observed. All venturing has value in some way and the contribution to society is diverse and considerable, including for example: wealth and job creating growth-oriented firms; the ability to work (for those disadvantaged or excluded from the labour market); the ability to manage socially valuable roles, such as caring or parenting while maintaining income; maintaining and developing skills and networks; and contributing to portfolio careers. Each of these are meritorious of research and policy engagement 
To conclude, we propose that the critical realist morphogenetic approach, applied to venturing via the four factor model and morphogenetic process presented in this paper, does much to inform our understanding of the empirically observed venturing landscape. To return to our original example, it explains that Richard Branson and the author's father were both reflexively driven initially in the context of their natal, educational, social and habitual backgrounds to start firms. In Richard Branson's case, informed by his circumstances and experiences, including his burgeoning business activities, he went on subsequently to create an empire. Dissimilarly, for the author's father, the business he started is the same one he has today, with a similar financial value. For him, it realised the value it was originally perceived to present, and through ongoing business and technical practice, sustainability and an income sufficient for the needs of everyday family life continue to be achieved. Concurrently, the ongoing esteem, autonomy and identity as an independent venturer reduce the attraction of employment. For each man, the antecedent conditions for venturing are distinct, a consequence of context and agency and the reflexive interaction of these throughout their lifetimes of experiences. The complex agential and contextual world is not the same for any two people and so their ambitions and foci, their attitudes and experiences, each and all have contributed to the development of the person in context. This enhances our understanding of why all persons are unique, why business outcomes are infinitely variable, and why the author's father is not like Richard Branson.

\section{References}

Ajzen, I. (1991) The Theory of Planned Behavior. Organizational behavior and human decision processes, 50 (2) pp. 179-211

Alvarez, S. A. and Barney, J. B. (2010) Entrepreneurship and epistemology: The philosophical underpinnings of the study of entrepreneurial opportunities. The Academy of Management Annals, 4 (1) pp. 557-583 
Anderson, A. R. (2015) Conceptualising entrepreneurship as economic'explanation'and the consequent loss of'understanding'. International Journal of Business and Globalisation, 14 (2) pp. 145-157

Aparicio, S., Urbano, D. and Audretsch, D. B. (2016) Institutional factors, opportunity entrepreneurship and economic growth: panel data evidence. Technological forecasting and social change, 102 pp. 45-61

Archer, M. S. (1995) Realist social theory: the morphogenetic approach, Cambridge: Cambridge University Press

Archer, M. S. (1998) Introduction: Realism in the social sciences. In: Archer, M. S., Bhaskar, R., Collier, A., Lawson, T.andNorrie, A. (eds.) Critical Realism: Essential readings. London: Routledge.

Archer, M. S. (2000) Being Human: The Problem of Agency, Cambridge: Cambridge University Press

Archer, M. S. (2003) Structure, Agency and Internal Conversation, Cambridge: Cambridge University Press

Archer, M. S. (2007) Making our way through the world - Human reflexivity and social mobility, Cambridge: Cambridge University Press

Armitage, C. J. and Conner, M. (2001) Efficacy of the Theory of Planned Behaviour: A metaanalytic review. British Journal of Social Psychology, 40 (4) pp. 471-499

Bae, T. J., Qian, S., Miao, C. and Fiet, J. O. (2014) The Relationship Between Entrepreneurship Education and Entrepreneurial Intentions: A Meta-Analytic Review. Entrepreneurship Theory and Practice, 38 (2) pp. 217-254

Bhaskar, R. (1979) Possibility of naturalism: A philosophical critique of the contemporary human sciences, Brighton: The Harvester Press Limited

Bird, B. and Jelinek, M. (1988) The Operation of Entrepreneurial Intentions. Entrepreneurship: Theory \& Practice, 13 (2) pp. 21-29

Bögenhold, D. and Staber, U. (1991) The decline and rise of self-employment. Work, Employment \& Society, 5 (2) pp. 223-239

Boxer, R., Perren, L. and Berry, A. (2016) SME managing director and nonexecutive director trust relations: The dynamic interplay between structure and agency. International Small Business Journal, 34 (3) pp. 369-386

Bygrave, W. D. (1994) The Portable MBA in Entrepreneurship, Hoboken, NJ: John Wiley \& Sons Inc.

Bygrave, W. D. and Hofer, C. W. (1992) Theorizing about Entrepreneurship. Entrepreneurship: Theory \& Practice, 16 (2) pp. 13-22

Clark, P. and Blundel, R. (2007) Penrose, critical realism and the evolution of business knowledge: A methodological reappraisal. Management \& Organizational History, 2 (1) pp. 45-62

Danermark, B., Ekstrom, M., Jakobsen, L. and Karlsson, J. C. (2002) Explaining Society: Critical reaslim in the social sciences, New York, NY: Routledge

Davidsson, P. (2017) Entrepreneurial opportunities as propensities: Do Ramoglou \& Tsang move the field forward? Journal of Business Venturing Insights, 7 pp. 82-85

Dimov, D. (2007) Beyond the Single-Person, Single-Insight Attribution in Understanding Entrepreneurial Opportunities. Entrepreneurship: Theory \& Practice, 31 (5) pp. 713 731

Donaldson, T. and Walsh, J. P. (2015) Towards a theory of business. Research in Organizational Behavior, 35 pp. 181-207

Elder-Vass, D. (2008) Integrating institutional, relational, and embodied structure: an emergenist perspective. British Journal of Sociology, 59 (2) pp. 281-299

Elder-Vass, D. (2010) The Causal Power of Social Structures: Emergence, Structure and Agency, Cambridge: Cambridge University Press 
Elfving, J. (2008) Contextualizing Entrepreneurial Intentions: Abo Akademi University Press Forbes (2019) Richard Branson Profile [online]. Available: https://www.forbes.com/profile/richard-branson/ [Accessed Feb 1, 2018].

Fuller, C. (2013) Reflexivity, relative autonomy and the embedded individual in economics. Journal of Institutional Economics, 9 (01) pp. 109-129

Gaglio, C. M. and Katz, J. A. (2001) The Psychological Basis of Opportunity Identification: Entrepreneurial Alertness. Small Business Economics, 16 (2) pp. 95-111

Gibson-Graham, J. K. (2006) The end of capitalism (as we knew it): A feminist critique of political economy, Minneapolis, MN: First University of Minnesota Press

Gibson-Graham, J. K. (2008) Diverse economies: performative practices forother worlds'. Progress in Human Geography, 32 (5) pp. 613-632

Gibson-Graham, J. K. (2010) Forging post-development partnerships. In: Pike, A., RodriguezPose, A.andTomaney, J. (eds.) Handbook of Local and Regional Development. London: Routledge.

Gritzas, G. and Kavoulakos, K. I. (2016) Diverse economies and alternative spaces: An overview of approaches and practices. European Urban and Regional Studies, 23 (4) pp. 917-934

Hessels, J., Gelderen, M. and Thurik, R. (2008) Entrepreneurial aspirations, motivations, and their drivers. Small Business Economics, 31 (3) pp. 323-339

Jones, P., Simmons, G., Packham, G., Beynon-Davies, P. and Pickernell, D. (2012) An exploration of the attitudes and strategic responses of sole-proprietor micro-enterprises in adopting information and communication technology. International Small Business Journal, 32 (3) pp. 285-306

Karp, T. (2006) The inner entrepreneur: A constructivistic view of entrepreneurial reality construction. Journal of Change Management, 6 (3) pp. 291-304

Kelley, D., Singer, S. and Herrington, M. (2016) Global Enterpreneurship Monitor 2015/16 Global Report [online] Available: file:///C:/Users/busikap/Downloads/gem-20152016-global-report-110416-1460370041.pdf [Accessed]

Kitching, J. and Rouse, J. (2017) Opportunity or dead end? Rethinking the study of entrepreneurial action without a concept of opportunity. International Small Business Journal, 35 (5) pp. 558-577

Korsgaard, S. and Anderson, A. R. (2011) Enacting entrepreneurship as social value creation. International Small Business Journal, pp. 0266242610391936

Kurczewka, A., Kyro, P. and Abbas, A. (2014) Transformative Capacity of Entrepreneurship Education in Two Different Cultural Settings - Morphogenetic Analysis of Egypt and Finland. Journal of Enterprising Culture, 21 (4) pp. 1-35

Lee, R. (2006) The ordinary economy: tangled up in values and geography. Transactions of the Institute of British Geographers, 31 (4) pp. 413-432

Lichtenstein, B. B., Carter, N. M., Dooley, K. J. and Gartner, W. B. (2007) Complexity dynamics of nascent entrepreneurship. Journal of Business Venturing, 22 (2) pp. 236261

Lopez, J. J. (2009) Book Reviews: Margaret S. Archer, Making our way through the world: Human reflexivity and social mobility. Canadian Journal of Sociology, 34 (1) pp. 173174

Maccarini, A. M. and Prandini, R. (2010) Human Reflexivity in Social Realism: Beyond the Modern Debate. In: Archer, M. S. (ed.) Conversations about Reflexivity: Ontological Explorations. London: Routledge, Taylor and Francis Group.

Manolova, T. S., Brush, C. G., Edelman, L. F. and Shaver, K. G. (2012) One size does not fit all: Entrepreneurial expectancies and growth intentions of US women and men nascent entrepreneurs. Entrepreneurship \& Regional Development, 24 (1-2) pp. 7-27 
Marks, A. and Huzzard, T. (2010) Employability and the ICT worker: a study of employees in Scottish small businesses. New Technology, Work and Employment, 25 (2) pp. 167181

Martin, L. and Wilson, N. (2014) Opportunity, discovery and creativity: A critical realist perspective. International Small Business Journal, 34 (3) pp. 261-275

McMullen, J. S. and Shepherd, D. A. (2006) Entrepreneurial action and the role of uncertainty in the theory of the entrepreneur. Academy of Management review, 31 (1) pp. 132-152

Meliou, E. and Edwards, T. (2018) Relational practices and reflexivity: Exploring the responses of women entrepreneurs to changing household dynamics. International Small Business Journal, 36 (2) pp. 149-168

Mochrie, R., Galloway, L. and Donnelly, E. (2006) Attitudes to growth and experience of growth among Scottish SMEs. International Journal of Entrepreneurial Behaviour \& Research, 12 (1) pp. 7-20

Morris, M. H., Nola, M. N., Craig, W. E. and Coombes, S. M. (2006) The dilemma of growth: understanding venture size choices of women entrepreneurs. Journal of Small Business Management, 44 (2) pp. 221-244

Office for National Statistics (2014) Record Proportion of People in Employment are Home Workers [online] Available: https://webarchive.nationalarchives.gov.uk/20160105210705/http://www.ons.gov.uk/ ons/rel/lmac/characteristics-of-home-workers/2014/sty-home-workers.html [Accessed Nov 28, 2018]

Office for National Statistics (2016) Women shoulder the responsibility of 'unpaid work' [online]. Office for National Statistics. Available: http://visual.ons.gov.uk/the-valueof-your-unpaid-work/ [Accessed July 20, 2017 2017].

Ogbor, J. O. (2000) Mythicizing and reification in entrepreneurial discourse: Ideology-critique of entrepreneurial studies. Journal of Management Studies, 37 (5) pp. 605-635

Orhan, M. and Scott, D. (2001) Why women enter into entrepreneurship: an explanatory model. Women In Management Review, 16 (5) pp. 232-243

Parker, S. C., Storey, D. J. and Witteloostuijn, A. V. (2010) What happens to gazells ? The importance of dynamic management strategy. Small Business Economics, 35 pp. $203-$ 226

Porter, M. E. (1996) What is Strategy? Harvard Business Review, November-December pp. 61-78

Ramgolou, S. and Tsang, E. (2017) Accepting the unknowables of entrepreneurship and overcoming philosophical obstacles to scientific progress. Journal of Business Venturing Insights, 8 pp. 71-77

Ramoglou, S. (2011) Who is a 'non-entrepreneur'?: Taking the 'others' of entrepreneurship seriously. International Small Business Journal, 31 (4) pp. 432-453

Ramoglou, S. and Tsang, E. (2016) A realist perspective of entrepreneurship: Opportunities as propensities. Academy of Management Review, 41 (3) pp. 410-434

Shane, S. (2003) A General Theory of Entrepreneurship: The Individual-Opportunity Nexus, Cheltenham, UK: Edward Elgar

Shane, S. and Venkataraman, S. (2000) The Promise of Entrepreneurship as a Field of Research. The Academy of Management Review, 25 (1) pp. 217-226

Shepherd, D. A., McMullen, J. S. and Jennings, P. D. (2007) The formation of opportunity beliefs: Overcoming ignorance and reducing doubt. Strategic entrepreneurship journal, 1 (1-2) pp. 75-95

Short, J. C., Ketchen, D. J., Shook, C. L. and Ireland, R. D. (2010) The Concept of "Opportunity" in Entrepreneurship Research: Past Accomplishments and Future Challenges. Journal of Management, 36 (1) pp. 40-65 
Sniehotta, F., Presseau, J. and Araújo-Soares, V. (2014) Time to retire the theory of planned behaviour. Health Psychology Review, 8 (1) pp. 1-7

Steyaert, C. and Katz, J. (2004) Reclaiming the space of entrepreneurship in society: geographical, discursive and social dimensions. Entrepreneurship \& Regional Development, 16 (3) pp. 179-196

Stirzaker, R. J., Galloway, L. and Potter, L. (2019) Business, Ageing and Socioemotional Selectivity: a Qualitative Study of Grey Entrepreneurship. Journal of Small Business Management (forthcoming).

Suddaby, R., Viale, T. and Gendron, Y. (2016) Reflexivity: The role of embedded social position and entrepreneurial social skill in processes of field level change. Research in Organizational Behavior, 36 pp. 225-245

Tedmanson, D., Verduyn, K., Essers, C. and Gartner, W. B. (2012) Critical perspectives in entrepreneurship research. Organization, 19 (5) pp. 531-541

Van Gelderen, M. and Jansen, P. (2006) Autonomy as a start-up motive. Journal of Small Business and Enteprise Development, 13 (1) pp. 23-32

Walker, E. and Brown, A. (2004) What Success Factors are Important to Small Business Owners? International Small Business Journal, 22 (6) pp. 577-594

Welter, F., Baker, T., Audretsch, D. B. and Gartner, W. B. (2017) Everyday entrepreneurshipa call for entrepreneurship research to embrace entrepreneurial diversity. Entrepreneurship Theory and Practice, 41 (3) pp. 311-321

Wiklund, J. and Shepherd, D. (2003) Aspiring for, and Achieving Growth: The Moderating Role of Resources and Opportunities*. Journal of Management Studies, 40 (8) pp. 1919-1941

Wood, M. S., McKelvie, A. and Haynie, J. M. (2014) Making it personal: Opportunity individuation and the shaping of opportunity beliefs. Journal of Business Venturing, 29 (2) pp. 252-272

Wood, M. S. and McKinley, W. (2018) The Entrepreneurial Opportunity Construct: Dislodge Or Leverage? Academy of Management Perspectives, pp. online

Young, L. (2013) Growing your Business: A report on growing micro businesses [online] Available: https://www.gov.uk/government/uploads/system/uploads/attachment_data/file/197726 /bis-13-729-growing-your-business-a-report-on-growing-micro-businesses.pdf [Accessed June 14, 2013]

Zahra, S. A., Wright, M. and Abdelgawad, S. (2014) Contextualization and the advancement of entrepreneurship research. International Small Business Journal, 32 (5) pp. 479-500 